Лапина М.А., Карпухин Д.В.

\title{
НАУЧНО-МЕТОДОЛОГИЧЕСКИЙ АНАЛИЗ ПРОБЛЕМНЫХ АСПЕКТОВ СИСТЕМАТИЗАЦИИ ФУНКЦИЙ И ПОЛНОМОЧИЙ ФЕДЕРАЛЬНЫХ ОРГАНОВ ИСПОЛНИТЕЛЬНОЙ ВЛАСТИ
}

\begin{abstract}
Аннотация. Предметом статьи является анализ действующего законодательства, регламентирующего правовой статус федеральных органов исполнительной власти и анализ имеющихся подходов к определению сущности их функций и полномочий. Выработка методологии по систематизации функций и полномочий станет основой для разработки моделей классификаторов функций и полномочий органов исполнительной власти и методики их подготовки и заполнения. Необходимость классификатора функций и полномочий органа исполнительной власти диктуется целями оптимизации государственного (муниципального) управления в соответствующих сферах и качественного улучшения процедур взаимодействия государства, физических и юридических лии. Методологическую основу статьи составили современные достижения теории познания. В процессе исследования применялись общерилософский, теоретический, общефилософские методы (диалектика, системный метод, анализ, синтез, аналогия, дедукция, наблюдение, моделирование), традиционно правовые методы (формально-логический), а также методы, используемые в конкретно-социологических исследованиях (статистические, экспертные оценки и др.), компаративистский (сравнительный), методы сегментации, типологизации, корреляции. Основной вывод, который сделан авторами заключается в необходимости соотнесения ведомственных функций и частных (отдельных) полномочий органов исполнительной власти посредством метода корреляции, в основе которого лежит парадигма о признании универсализма частных (отдельных) функций для отраслевых (ведомственных) функций органов государственной исполнительной власти.Основным вкладом авторов является разработка методологии систематизации функций и полномочий федеральных органов исполнительной власти, которая станет основой для разработки моделей классификаторов функций и полномочий органов исполнительной власти и методики подготовки и заполнения классификатора функций и полномочий органа исполнительной власти в целях оптимизации государственного (муниципального) управления в соответствующих срерах и качественного улучшения процедур взаимодействия государства, физических и юридических лиц.
\end{abstract}

Ключевые слова: управление, процесс управления, субъекты управления, исполнительная власть, систематизация, функция, полномочия, методология, классификатор, современные ИТ.

Abstract. The research subject is the analysis of the current legislation regulating the legal status of federal executive authorities, and the analysis of the existing approaches to defining their essence, functions and responsibilities. The methodology of systematizing functions and responsibilities will serve as a basis for the development of classification models for the functions and responsibilities of executive authorities and the methodology of their preparation and processing. The need for the classifier of functions and responsibilities of executive authorities is determined by the purposes of optimization of public (municipal) administration in the respective spheres and a qualitative improvement of the procedures of interaction between the state and physical and legal entities. The research methodology is based on the recent achievements of epistemology. The authors apply general scientific and theoretical research methods (dialectics, the system method, analysis, synthesis, analogy, deduction, observation, and modeling), traditional legal methods (formal-logical), and the methods of specific sociological studies (statistical, expert assessments, etc.), the methods of segmentation, classification, and correlation, and the comparative method. The authors conclude that it is necessary to correlate the departmental functions and the private (specific) responsibilities of executive authorities by means of the correlation method based on the paradigm admitting the universalism of private (specific) functions for the sectoral (departmental) functions of executive authorities. The authors develop the methodology of systematizing the functions and responsibilities of federal executive authorities and the methodology of preparation and processing the classifier of functions and responsibilities of the executive agency for the purpose of optimizing the public (municipal) administration in the respective spheres and a qualitative improvement of the procedures of interaction between the state and physical and legal entities.

Key words: administration, management, subjects of administration, executive authority, systematization, function, responsibilities, methodology, classifier, modern information technologies

Статья подготовлена по результатам исследований, выполненных

за счет бюджетных средств по Государственному заданию Финансового университета при Правительстве Российской Федерации 2015 г. 
C тратегия развития информационного общества, Стратегия национальной безопасности ориентируют российское общество на мобилизацию продуктивного использования ресурсов информационно-коммуникационных технологий и в то же время на обновление и укрепление основных параметров организации государственного и общественного управления.

Управленческая деятельность как процесс возникает при наличии объекта (ов), нуждающегося в управлении для поддержания его функционирования и создания результата, необходимого обществу; субъекта, способного действовать адекватно ожиданиям общества и возможностям объекта выдать ожидаемый продукт (результат); понимание цели взаимодействия субъекта управления и способность объекта воспринимать целевые установки и ресурсы - материальные, финансовые, кадровые, информационные и пр. В системе государственного управления субъектом управления является система органов государственной власти (ОГВ), а объектом выступает деятельность этой системы, которая обязана выдать ожидаемый результат [19; 14; 15,С. 135-145]. И это не материальные объекты, как в области производства материального, а качество управления и степень организации работы системы ОГВ. Это значит, что первым уровнем управления является самоорганизация системы ОГВ, а в плане нашего задания - качество самоорганизации системы исполнительной власти. Результатом, получаемым обществом, в данном случае становится деятельность управляемых объектов в структуре хозяйства, экономики, образования, здоровья населения, условий жилья и работы граждан.

В статье «Методология анализа оценки состояния и совершенствования государственного управления в условиях информатизации» И.Л. Бачилоотмечает, чтобы процесс управления состоялся, необходимы определенные условия, обеспечивающие качество управления. Таковыми являются в первую очередь такие механизмы и параметры организации процесса управленческой деятельности ОИВ. Основными параметрами самоорганизации в системе управления кроме наличия специалистов и ресурсов являются такие инструменты как функции и полномочия органов при четком определении их сферы деятельности, их ведения и ответственности [15,С. 135-145].

Первым и исходным базовым параметром являются систематизированные и легализованные законом функции государственного управления. Термин «функция» определяется как деятельность. Но применительно к конкретной сфере деятельности - это указание на предмет деятельности, на то, ЧТО субъект делает в определенной области и что он должен представить как резуль- тат своей деятельности. В управлении - это указание на то, в какой области и что делает субъект управления - орган, его подразделения, служащие системы государственной службы. Вторым главным параметром управления является категория «полномочия субъекта управления» - указатель того, каким образом и средствами, закрепленными законодательно, достигает субъект управления реализации своих функций [15, С. 135-145].

Однако до сих пор в законодательной практике нет устойчивого понятия и правовой дефиниции терминов «функции управления», «функции государственного управления» и назначения и смысла самого концепта - «функции». Функция - важнейшая категория организации и качества управления. По исследованию природы и назначению функций как важнейшего параметра организации управления существует большой массив литературы. Однако итогом многих исследований по этому вопросу является вывод о необходимости системного и комплексного представления всего спектра функциональной деятельности в области государственного управления [12, С. 48-64; 17 , С. 127-148; 18, С. 28-47].

Вторым базовым параметром процесса организации и функционирования системы управления является концепт (собирательный термин) полномочий субъектов управленческой деятельности. Это важнейший путеводитель и индикатор качества реализации функций органа и системы управления, включая и область продуктивного использования программных продуктов ИКТ в системе государственного управления. Правило «бери, что дают» и приспосабливай к своим нуждам, надо менять на девиз: «изготовь, что требуется» и поставляй по запросу, отвечай за качество и безопасность продукта[15, С. 135-145].

И.Л. Бачило отмечает, что при разработке методологии организации электронного государственного управления важно учитывать дихотомическую связь функций и полномочий в процессе организации деятельности субъектов управления. Модель взаимосвязи функций и полномочий субъектов исполнительной власти является определяющим принципом организации системы и качества ее деятельности. Функции определяют, ЧТО делает каждый элемент инфраструктуры управления. Полномочия (правомочия) устанавливают то, как, какими правовыми и организационными средствами субъект достигает поставленной цели для сферы управления, как он реализует свои функции. Проблема связи этих параметров организации является краеугольным камнем во всей системе управленческой деятельности. Эта проблема является предметом внимания правовой, управленческой науки и законодательства; это область того 


\section{Административное и муниципальное право 4 (100) 2016}

информационного пространства, в котором формируются и реализуются первичные и итоговые информационные ресурсы, качество и состояние которых определяет всю судьбу системы управления и решение проблем качества жизни человека и всего общества[15, С. 135-145].

В соответствии со статьёй 2 Указа Президента Российской Федерации от 09.03.2004 N 314 “О системе и структуре федеральных органов исполнительной власти" (далее - Указ Президента № 314) выделено 4 (четыре) функции, которые могут осуществлять федеральные органы исполнительной власти[4]:

- во-первых, функция по принятию нормативно-правовых актов, под которой понимается издание на основании и во исполнение Конституции Российской Федерации, федеральных конституционных законов, федеральных законов обязательных для исполнения органами государственной власти, органами местного самоуправления, их должностными лицами, юридическими лицами и гражданами правил поведения, распространяющихся на неопределенный круг лиц;

- во-вторых, функция по контролю и надзору, под которой в Указе понимается:

- осуществление действий по контролю и надзору за исполнением органами государственной власти, органами местного самоуправления, их должностными лицами, юридическими лицами и гражданами установленных Конституцией Российской Федерации, федеральными конституционными законами, федеральными законами и другими нормативными правовыми актами общеобязательных правил поведения;

- выдача органами государственной власти, органами местного самоуправления, их должностными лицами разрешений (лицензий) на осуществление определенного вида деятельности и (или) конкретных действий юридическим лицам и гражданам;

- регистрация актов, документов, прав, объектов, а также издание индивидуальных правовых актов;

- в-третьих, функция по управлению государственным имуществом, под которой понимается осуществление полномочий собственника в отношении федерального имущества, в том числе переданного федеральным государственным унитарным предприятиям, федеральным казенным предприятиям и государственным учреждениям, подведомственным федеральному агентству, а также управление находящимися в федеральной собственности акциями открытых акционерных обществ;

- в-четвёртых, функция по оказанию государственных услуг, под которой понимается пре- доставление федеральными органами исполнительной власти непосредственно или через подведомственные им федеральные государственные учреждения либо иные организации безвозмездно или по регулируемым органами государственной власти ценам услуг гражданам и организациям в области образования, здравоохранения, социальной защиты населения и в других областях, установленных федеральными законами.

В первоначальной редакции Указа Президента РФ N 314 среди функций перечислялась и правоприменительная, под которой понималось “издание индивидуальных правовых актов, а также ведение реестров, регистров и кадастров", но впоследствии она была отменена[4]. Причинами изъятия данной функции из функционального перечня федеральных органов исполнительной власти объясняется тем, что эта функция свойственна любому органу публичной власти, и, в первую очередь органа исполнительной власти, по сути являясь формой реализации его деятельности. При осуществлении всех других функций (и функции по управлению государственным имуществом, и функции по оказанию государственных услуг, и контрольно-надзорную функции) федеральный орган исполнительной власти реализует правоприменительную функцию.

Следует отметить, что изъятие правоприменительной функции из перечня функций, реализуемых федеральными органами исполнительной власти, не означает полного принципиального отказа от её самостоятельного статуса в перечне функций, реализуемых органами исполнительной власти, так как функции по управлению государственным имуществом и по оказанию государственных услуг, по сути, являются правоприменительными. На «размытость» и «рассредоточенность» правоприменительной функции в Указе Президента № 314 обращают внимание многие ученые-административисты. Так, Ю.Н. Старилов задает справедливый вопрос: почему из всех правоприменительных функций выделили две по управлению имуществом и по оказанию услуг? Ученый предлагает дополнить этот перечень, к примеру, по сбору налогов или оптимальному выполнению федерального бюджета и т.п. [24].

В соответствии рассматриваемого Указа в систему федеральных органов исполнительной власти входят федеральные министерства, федеральные службы и федеральные агентства.

Таким образом, в основе классификации функций федеральных органов исполнительной власти была положена форма реализации деятельности органа исполнительной власти (правотворческая или правоприменительная), а в основу разграниче- 
ния федеральных органов исполнительной власти на министерства, агентства и службы был положен принцип реализуемого объема функций. При этом, по справедливой оценке А.В. Кирина и Н.И. Побежимовой, разработчики проекта Указа Президента РФ № 314 - чиновники аппарата Правительства РФ и Минэкономразвития России ориентировались лишь на субъективные представления и предпочтения, обусловленные “привязкой” к их же определениям трех новых видов федеральных органов исполнительной власти [21, С. 67-71].

В этом же Указе Президента РФ № 314 перечни функций для федеральных министерств, федеральных служб и федеральных агентств не являются закрепленными исключительно за перечисленными федеральными органами исполнительной власти.

Так, в соответствии с пунктом «в» статьи 3 Указа Президента № 314 федеральное министерство имеет право в случаях, установленных законом, осуществлять функции по контролю и надзору, а также функции по управлению государственным имуществом. Федеральные службы (пункт «в» статьи 4 Указа Президента № 314 вправе в случаях, установленных указами Президента Российской Федерации или постановлениями Правительства Российской Федерации осуществлять нормативно-правовое регулирование. Правомочиями по осуществлению контрольно-надзорных функций и нормативноправовому регулированию, в случаях, установленных указами Президента Российской Федерации или постановлениями Правительства Российской Федерации, обладают федеральные агентства.

Наличие указанных отсылочных норм создаёт правовой потенциал для концентрации правотворческих, правоприменительных (управление государственным имуществом, оказание государственных услуг и контрольно-надзорных функций) в федеральных министерствах, правотворческих и правоприменительных (в большей мере контрольно-надзорных функций) в федеральных службах, правотворческих, правоприменительных (в большей мере оказания государственных услуг[29]) в федеральных агентствах.

В действующей редакции Указа Президента РФ N 314 классификации функций с точки зрения теории права, административного права, теории государственного управления были взяты различные основания: не только правовые формы реализации, но и отдельные управленческие и исполнительнораспорядительные функции. В результате получился некий, концептуально не обоснованный перечень основных функций федеральных органов исполнительной власти, который не всегда коррелируется с законодательно установленной компетенцией того или иного органа исполнительной власти и тем бо- лее не коррелируется с функциями и полномочиями, установленными соответствующими положениями об органах исполнительной власти.

В период проведения административной реформы (в частности, в 2003- 2006 г.) была поставлена цель уменьшить общее количество функций федеральных органов исполнительной власти, их систематизировать, проанализировать и, пожалуй, самое главное, разграничить полномочия между тремя ведомствами, входящими в систему федеральных органов исполнительной власти. Нами ранее отмечалось, что правильнее было бы для федеральных министерств оставить функцию ведомственного нормотворчества, право законотворческих инициатив, координации и внутриведомственного контроля за деятельностью входящих в него служб и агентств.

Для федеральных служб предложить правоохранительную функцию, включающую в себя надведомственный контроль и надзор, разрешительную деятельность, обеспечение правопорядка и т.п.

И наконец, для федеральных агентств - регулятивную, непосредственно правоприменительную (исполнительную) (в узком понимании этого слова) в рамках своих полномочий: вопросы государственного регулирования и государственного управления в той или иной сфере, области, включая управление государственным имуществом, оказание государственных услуг и т.п. [22].

Следует также отметить, что Указ Президента РФ № 314 не является единственным нормативным правовым актом, в котором содержится формальное определение категории «функция», ее соотношение с понятием «реализация функции» и «полномочия», функции по контролю и надзору, функции по предоставлению государственных услуг [33, С. 84-97; 34, С. 115-117; 35, С. 52-72], обязанности и т.д.К примеру, ст.2 Федерального закона от 27.07.2010 N 210-Ф3 “Об организации предоставления государственных и муниципальных услуг” (с изм. и доп., вступ. в силу с 15.09.2015) определение государственной услуги трактуется как деятельность по реализации функций соответствующего органа, которая осуществляется по запросам заявителей в пределах установленных нормативными правовыми актами полномочий органов, предоставляющих государственные услуги[1].

Другой пример: в официальном документе Распоряжении Правительства РФ от 10 мая 2014 г. № 793-р «Концепция систематизации и кодирования информации, а также совершенствования и актуализации общероссийских классификаторов, реестров и информационных ресурсов» к функциям отнесены те области (предметы) деятельности, которые касаются «обязанностей федеральных органов, осуществляющих функции по выработке го- 


\section{Административное и муниципальное право 4 (100) 2016}

сударственной политики и нормативно-правовому регулированию в установленных сферах деятельности, по согласованию с органом исполнительной власти, осуществляющим межведомственную координацию в сфере систематизации и кодирования информации» [9].

В ст.2 законопроекта «Об основах государственного и муниципального контроля (надзора) в Российской Федерации» содержится определение федерального государственного контроля (надзора), под которым понимается «осуществляемая в пределах установленных полномочий деятельность федеральных органов исполнительной власти, иных уполномоченных органов и организаций, направленная на предупреждение, выявление и пресечение нарушений гражданами и организациями, их руководителями и иными должностными лицами, их уполномоченными представителями обязательных требований, принятие предусмотренных законодательством Российской Федерации мер по пресечению выявленных нарушений, а также деятельность указанных уполномоченных органов и организаций по систематическому анализу и прогнозированию состояния исполнения обязательных требований при осуществлении деятельности гражданами и организациями» [23]. То есть по сути речь идет о правоохранительной составляющей правоприменительной функции органов исполнительной власти.

Нельзя не отметить, что определение отдельных функций, которые часто заменяют полномочиями по принятию нормативных правовых актов и актов локальных, также содержится в законодательстве по административной реформе 2004 г.

Таким образом, понятие «функция органа исполнительной власти» по своей природе является весьма ёмкой категорией, охватывающей правотворческую, правоприменительную (оказание государственных услуг, управление государственным имуществом, контрольно-надзорную виды деятельности), каждый из которых также характеризуется широким содержательным сегментом, что было проиллюстрировано на примере правоприменительной функции федерального органа исполнительной власти.

Понятие полномочие по своей правовой природе является более узкой смысловой категорией, так как закрепляет специфический организационно-правовой инструментарий, посредством которого воплощаются основные направления деятельности (функции) федерального органа исполнительной власти.

Для наглядности соотношений понятий «функция» и «полномочие» государственного органа исполнительной власти приведём таблицу 4, опубликованную в статье И.Л. Бачило. Она посвя- щена полномочиям органам исполнительной власти и представляет перечень терминов, которыми обозначаются полномочия органов исполнительной власти [15, С. 135-145].

К этой классификации полномочий ФОИВ добавим перечень терминов по Указу Президента РФ от 12 марта 2004 г. № 314. В этом документе перечислены такие полномочия, как: «учреждает», «вносит», «имеет право», «назначает», «координирует», «осуществляет», «принимает НПА». В рекомендациях по реализации плана - графика по подготовке административных регламентов для Федеральных органов исполнительной власти по исполнению функций и государственных услуг приведена следующая классификация полномочий, реализуемых органами:

а) исполнительские (выдает, осуществляет, исполняет);

б) разрешительные (лицензии, сертификаты, разрешения, аккредитации);

в) контрольно-надзорные;

г) учетно-регистрационные;

д) организационные;

е) обеспечительные;

ж) рассмотрение;

з) согласование;

и) решение.

Наряду с этим стоит задача «сформулировать смежные и связанные по функциям ФОИВ в целях согласованности административных регламентов по смежным функциям; рассматривать предметы деятельности с точки зрения отнесения их к функциям (это делает, согласно этим рекомендациям, сам орган) и услуг, которые передаются на исполнение соответствующим ответственным (подведомственным) структурам. Из этого документа можно сделать вывод: пока нет четкого разграничения функций и полномочий; предоставление услуг не рассматривается как одна из многих функций управления. Нет различия или однозначности терминов «разрешает» и «решает».

Ю.А. Тихомиров предлагает выделять «наиболее типичные полномочия с обусловленным операциональным делением - видовые и более конкретные полномочия:

a) руководит - полнообъемное решение вопросов и выполнение всех нижеследующих полномочий;

б) управляет - императивные указания, распоряжения, включает часть конкретных полномочий;

в) решает - устанавливает, определяет, утверждает, создает, оформляет, представляет. Членение возможно по степени самостоятельности принятия решений:

- независимо (самостоятельно);

- по согласованию;

- совместно; 
Частота использования терминов, обозначающих основные полномочия органов исполнительной власти

\begin{tabular}{|c|c|c|c|c|c|}
\hline \multirow{2}{*}{$\begin{array}{c}\text { Термины, отражающие } \\
\text { характер полномочия }\end{array}$} & $\begin{array}{c}\text { CM } \\
\text { CCCP }\end{array}$ & Правительство РФ & $\begin{array}{c}\text { Министерства } \\
\text { СССР } \\
\end{array}$ & $\begin{array}{l}\text { Министерство } \\
\text { экономики РФ }\end{array}$ & \begin{tabular}{|c|} 
Министерство \\
труда РФ \\
\end{tabular} \\
\hline & 1 & 2 & 3 & 4 & $\mathbf{5}$ \\
\hline 1. Распорядительные & 17 & 15 & 29 & 4 & 15 \\
\hline 1.1. Решает (реализует) & 4 & 5 & 4 & 2 & 3 \\
\hline 1.2. Определяет (создает, отменяет) & 8 & 3 & - & - & 2 \\
\hline 1.3. Устанавливает & 1 & 4 & 10 & - & 4 \\
\hline 1.4. Утверждает & 3 & 2 & 14 & 2 & 6 \\
\hline 15. Назначает & 1 & 1 & 1 & - & - \\
\hline 2. Регулирующие & 22 & 8 & 17 & 7 & 8 \\
\hline 2.1. Руководит (Регулирует). & 9 & 4 & 6 & 2 & 1 \\
\hline 2.2.Рассматривает & 3 & 2 & 4 & - & 1 \\
\hline 2.3. Предлагает & 4 & 1 & 7 & 5 & 6 \\
\hline 2.4. Направляет & 6 & 1 & - & - & - \\
\hline 3. Организационно-контрольные & 44 & 37 & 54 & 22 & 18 \\
\hline 3.1. Организует & 8 & 4 & 11 & 5 & - \\
\hline 3.2. Обеспечивает & 13 & 19 & 27 & 5 & - \\
\hline 3.3. Координирует & 5 & 2 & 1 & 5 & 7 \\
\hline 3.4. Согласовывает & 3 & 1 & 2 & 2 & 3 \\
\hline 3.5. Контролирует & 3 & 4 & 9 & 5 & 8 \\
\hline 3.6. Принимает меры & 12 & 7 & 4 & - & - \\
\hline 4. Исполнительские & 29 & 32 & 48 & 33 & 72 \\
\hline 4.1. Разрабатывает (подготавливает) & 10 & 9 & 19 & 14 & 37 \\
\hline 4.2. Представляет & 3 & 3 & - & - & 1 \\
\hline 4.3. Учитывает & 1 & - & 2 & - & 3 \\
\hline 4.4. Отчитывается (доклад) & 3 & 1 & 1 & - & 4 \\
\hline 4.5. Осуществляет (меры) & 12 & 17 & 19 & 6 & 17 \\
\hline 4.6. Анализирует (обобщает) & - & - & 4 & 2 & 2 \\
\hline 4.7. Участвует (содействует) & - & 2 & 3 & 11 & 10 \\
\hline & 112 & 92 & 194 & 66 & 113 \\
\hline
\end{tabular}

- предварительно;

- рекомендательно;

г) участвует - формирование, разработка, согласование, порядок использования (имущества и т.п.), содействие;

д) нормирует - введение правил, принятие правовых актов, установление нормативно-технических и иных документов. Примечательно, что правовые акты могут играть троякую роль - как предметы ведения, как вид полномочия и как средство реализации компетенции в целом, о чем подробнее будет сказано далее;

е) организует - создает условия, стимулирует, поддерживает, выполняет, осуществляет, инструктирует;

ж) разрабатывает - предложения, проекты, программы, прогнозы, аналитическую информацию;

3) указывает - отмена актов, приостановление действий, создание организаций, предписание по совершению действий;

и) координирует - объединение планов и программ, согласование актов, действий и позиций, целевые установки, информационное обеспечение;

к) контролирует - проверка, ревизии, отчеты, информации. Эти полномочия неодинаковым образом комбинируются у различных субъектов компетенции. Причем здесь особенно важна точная мера дробления полномочия, т.е. легальная операционализация;

л) запрещает - отменяет, признает недействительным; приостанавливает» [26; 27].

Разнообразие подходов к перечню функций и полномочий говорит о необходимости установления более строгого порядка разграничения этих базовых инструментов в области упорядочения деятельности органов исполнительной власти в целом.

В то же время следует подчеркнуть, что приведённые классификации полномочий органов исполнительной власти, несмотря на определённые различия, имеют общее методологическое начало - типологизацию полномочий на базовые и частные (отдельные). К числу базовых следует отнести распорядительные, регулирующие, организационно-контрольные, исполнительские полномочия. В основу их выделения в самостоятельные группы положен принцип организационно - регулирующего воздействия. Наконец, частные (отдельные) полномочия реализуются в рамках базовых полномочий и охватывают полномочия, связанные с реализацией, созданием, отменой, установлением, утверждением, назначением, руководством (регулированием), предложением, на- 


\section{Административное и муниципальное право 4 (100) 2016}

правлением, организацией, обеспечением, координацией, согласованием, контролем, принятием мер, разработкой (подготовкой), представлением, учетом, отчётом, осуществлением, анализом и участием. Главная методологическая сложность соотнесения базовых и частных полномочий заключается в том, что последние, как правило, не выделены в нормативных правовых актах как самостоятельные полномочия федеральных органов исполнительной власти, но используются в качестве терминов, отражающих характер полномочия. Следовательно, метод типологизации - выявление общих или сходных черт указанных терминов, позволяет объединить последние в указанные четыре группы.

Следует также отметить, что на формальноюридическом уровне перечень функций федеральных органов исполнительной власти, содержащейся в Указе Президента РФ № 314 не является исчерпывающим. Так, в Распоряжении Правительства РФ от 10 мая 2014 г. № 793-р «Концепция систематизации и кодирования информации, а также совершенствования и актуализации общероссийских классификаторов, реестров и информационных ресурсов» отмечено, что в настоящее время в «в ряде значимых для взаимодействия органов государственной власти, физических и юридических лиц социально-экономических сфер полностью отсутствуют информационные ресурсы, которым может быть присвоен статус базовых государственных информационных ресурсов. В частности, отсутствует единая система учета населения, который осуществляется различными органами государственной власти для выполнения ведомственных функций - Федеральной миграционной службой, Федеральной налоговой службой, Пенсионным фондом Российской Федерации, органами записи актов гражданского состояния. Это обстоятельство не позволяет обеспечить полноценную идентификацию гражданина Российской Федерации для различных целей, в том числе для предоставления льгот, выдачи субсидий, корректного расчета государственного (муниципального) задания, статистики».

Проиллюстрированное положение нормативного правового акта позволяет констатировать наличие не только функций федеральных органов исполнительной власти, которые охватывают правотворческие, контрольно-надзорные функции и функции по управлению государственным имуществом и оказанию государственных услуг, изложенных в Указе Президента РФ № 314, но и базовых (ведомственных, отраслевых) функций, которые реализуют федеральные органы исполнительной власти в зависимости от специфики осуществляемого вида деятельности.
Таким образом, можно выделить категорию родовых функций федеральных органов исполнительной власти, закрепленных в Указе Президента РФ № 314. Однако наличие отраслевого принципа функционирования федеральных органов исполнительной власти (оборона, финансы, общественная безопасность, наука, образование, и т.д.) предполагает спецификацию родовых функций органов исполнительной власти применительно к определённой сфере общественных отношений.

Следует отметить, что данная спецификация родовых функций федеральных органов исполнительной власти также содержится в нормативных правовых актах: указах Президента РФ и постановлениях Правительствах РФ, в соответствии с которыми утверждены Положения о статусе федеральных министерств, федеральных служб, федеральных агентств.

Например, в статье 1 Постановления Правительства РФ от 30.06.2004 N 329 «О Министерстве финансов Российской Федерации» (действ.ред.) содержатся основные направления функциональной деятельности министерства в рамках родовой функции по выработке государственной политики и нормативно-правовому регулированию в сфере бюджетной, налоговой, страховой, валютной, банковской деятельности, кредитной кооперации, микрофинансовой деятельности, финансовых рынков, государственного долга, аудиторской деятельности, бухгалтерского учета и бухгалтерской отчетности, производства, переработки и обращения драгоценных металлов и драгоценных камней, таможенных платежей, определения таможенной стоимости товаров, формирования и инвестирования средств пенсионных накоплений, в том числе включенных в выплатной резерв, организации и проведения лотерей, азартных игр, производства и реализации защищенной от подделок полиграфической продукции, финансового обеспечения государственной службы, государственного регулирования деятельности негосударственных пенсионных фондов, управляющих компаний, специализированных депозитариев и актуариев по негосударственному пенсионному обеспечению, обязательному пенсионному страхованию и профессиональному пенсионному страхованию (за исключением государственного регулирования правоотношений между негосударственным пенсионным фондом и участниками негосударственного пенсионного фонда, застрахованными лицами и их правопреемниками, а также в части правоотношений, субъектом которых является Пенсионный фонд Российской Федерации), бюро кредитных историй, оказания государственной поддержки субъектам Российской Федерации и муниципальным образованиям за счет бюджетных 
ассигнований федерального бюджета. Кроме того, Министерство финансов Российской Федерации разрабатывает во взаимодействии с Центральным банком Российской Федерации основные направления развития финансового рынка[39].

Изложенный перечень функций можно объединить в несколько групп базовых функций, органически вытекающих из родовой функции, связанной с правотворческой деятельностью.

Перечень данных групп функций условно можно представить следующим образом:

1. Управление в бюджетной сфере деятельности.

2. Управление в налоговой сфере деятельности..

3. Управление в страховой сфере деятельности.

4. Управление в валютной сфере деятельности.

5. Управление в сфере банковской деятельности, кредитной кооперации, микрофинансовой деятельности, финансовых рынков, государственного долга, бюро кредитных историй.

6. Управление в сфере аудиторской деятельностью, бухгалтерского учета и бухгалтерской отчетности.

7. Управление в сфере производства,переработки и обращения драгоценных металлов и драгоценных камней.

8. Управление в сфере таможенных платежей, определения таможенной стоимости товаров.

9. Управление с сфере формирования и инвестирования средств пенсионных накоплений, в том числе включенных в выплатной резерв,

10. Управление в сфере государственного регулирования деятельности негосударственных пенсионных фондов, управляющих компаний, специализированных депозитариев и актуариев по негосударственному пенсионному обеспечению, обязательному пенсионному страхованию и профессиональному пенсионному страхованию

11. Управление в сфере организации и проведения лотерей, азартных игр, производства и реализации защищенной от подделок полиграфической продукции.

12. Управление в сфере финансового обеспечения государственной службы.

13. Оказание государственной поддержки субъектам Российской Федерации и муниципальным образованиям за счет бюджетных ассигнований федерального бюджета.

Следовательно, наряду с родовыми функциями органов исполнительной власти можно выделить базовые функции исполнительной власти, которые раскрывают отраслевую специфику управленческой деятельности. Их можно также обозначить как ведомственные функции.

Таким образом, наряду с дихотомией базовые полномочия - частные (отдельные) полномочия можно выделить дихотомию родовые функции базовые (ведомственные, отраслевые) функции. Выделение базовых (ведомственных, отраслевых) функций из родовых составляет содержание метода сегментации.

Методологический подходы по типологизации полномочий и сегментации функций, позволяют не только четко обозначить функции и полномочия государственных органов исполнительной власти, но и соотнести их между собой посредством метода корреляции ведомственных функций и частных полномочий. В основе корреляции ведомственных функций и частных полномочий лежит парадигма о признании универсализма частных (отдельных) функций для отраслевых (ведомственных) функций органов государственной исполнительной власти.

Следует также отметить, в общетеоретическом плане в государственном управлении под функциями понимают основные направления деятельности.

Существует несколько критериев классификации функций: в зависимости от формы реализации, по отраслевому принципу и организации управленческого процесса.

В контексте предлагаемых методологических подходов к определению и классификации функций органов исполнительной власти, большой интерес представляет методология, которая рассматривает главные функции управленческих органов как виды воздействий на объекты управления. Они расчленяются на подфункции, действия и операции с разной степенью властности. В основу данной методологии использования при определении метода сегментации - выделения из общих (родовых) функций ведомственных функций взят подход, предложенный в монографии «Исполнительная власть в Российской Федерации. Проблемы развития» [19; 16].

Кроме того, анализ существующих положений о ФОИВ выявил, отсутствие чёткого разграничения дефиниций «функция» и «полномочие» органов исполнительной власти на формально - юридическом уровне; подмену понятия функция понятием полномочие; идентичную буквальную трактовку содержания понятий «функция» и «полномочие» в нормативных правовых актах.

Так, Положение о Министерстве внутренних дел Российской Федерации, утвержденное Указом Президента РФ от 01.03.2011 N 248 «Вопросы Министерства внутренних дел Российской Федерации» (ред. от 03.08.2015) имеет следующие разделы-рубрикаторы: в п.1 1 перечень функций; в п. 3 пять основных задач; во втором разделе перечень полномочий (всего 68). При этом перечень полномочий остаётся открытым, поскольку п. 68 гласит 


\section{Административное и муниципальное право 4 (100) 2016}

«осуществляет иные полномочия в сфере внутренних дел»[2].

Пункт 1 Положения определяет Министерство внутренних дел Российской Федерации (МВД России) как федеральный органом исполнительной власти и содержит родовую функцию по выработке и реализации государственной политики и нормативно-правовому регулированию в сфере внутренних дел.

В соответствии с пунктом 3 Положения основными задачами МВД России являются:

1) разработка и реализация государственной политики в сфере внутренних дел;

2) нормативно-правовое регулирование в сфере внутренних дел;

3) обеспечение защиты жизни, здоровья, прав и свобод граждан Российской Федерации, иностранных граждан, лиц без гражданства (далее также - граждане; лица), противодействие преступности, охрана общественного порядка и собственности, обеспечение общественной безопасности;

4) управление органами внутренних дел Российской Федерации (далее - органы внутренних дел) и внутренними войсками МВД России (далее - внутренние войска);

5) обеспечение социальной и правовой защиты сотрудников органов внутренних дел, военнослужащих внутренних войск, федеральных государственных гражданских служащих системы МВД России, а также социально-правовое обеспечение работников системы МВД России, граждан, уволенных со службы в органах внутренних дел и с военной службы, членов их семей, иных лиц, соответствующее обеспечение которых на основании законодательства Российской Федерации возложено на МВД России.

Как видим отраслевые, ведомственные функции представлены в Положении в качестве задач Министерства.

Обширный перечень полномочий, содержащейся во 2 разделе Положении, используется как правило для обозначения функции или в связки полномочия-функции.

Аналогичную структуру имеют и другие министерства, руководство деятельностью которых осуществляет Президент РФ. Так, в положении о Министерстве иностранных дел, утверждённом Указом Президента РФ от 12.03.2015 N 129 «Вопросы Министерства иностранных дел Российской Федерации» содержатся 8 задач Министерства, которые, по сути являются ведомственными функциями и перечень из 49 полномочий, также заканчивающиеся «иными функциями» [3].

Кратко, анализируя положения о министерствах, руководство деятельностью которых осу- ществляет Правительство РФ, следует обратить внимание на несколько иную структурированность самих положений.

Например, в Положении о Минздраве России, утверждённым Постановлением Правительства РФ от 19.06.2012 N 608 (ред. от 03.06.2015) «Об утверждении Положения о Министерстве здравоохранения Российской Федерации» отсутствует пункт «задачи», а ведомственные функции изложены в пункте 1 раздела «Общие положения» [5]. Однако это не решает методологических проблем при раскрытии полномочий - подмены понятия «функция» понятием «полномочие», констатацией связок функция-полномочие, что значительно затрудняет систематизацию функций и полномочий органов государственной исполнительной власти. Кроме того, перечень полномочий также является открытым и заканчивается словами «иными функциями».

Аналогичную структуру и проблемы в части обозначения и разграничения ведомственных функций и полномочий имеет Положение о Министерстве финансов Российской Федерации, утверждённое Постановлением Правительства РФ от 30.06.2004 N 331 (ред. от 04.09.2015) «Об утверждении Положения о Министерстве здравоохранения Российской Федерации» [7].

Следует также кратко остановиться на анализе норм о функциях и полномочиях, содержащихся в положениях о федеральных службах.

Так, Положение о ФАС России, утверждённое Постановлением Правительства РФ от 30.06.2004 N 331 (ред. от 04.09.2015) «Об утверждении Положения о Федеральной антимонопольной службе» определяет Федеральную антимонопольную службу (ФАС России) в качестве уполномоченного федерального органа исполнительной власти, осуществляющего функции по принятию нормативных правовых актов и контролю за соблюдением антимонопольного законодательства, законодательства в сфере деятельности субъектов естественных монополий, в сфере государственного регулированияцен (тарифов) на товары (услуги), рекламы, контролю за осуществлением иностранных инвестиций в хозяйственные общества, имеющие стратегическое значение для обеспечения обороны страны и безопасности государства, контролю (надзору) в сфере государственного оборонного заказа и в сфере закупок товаров, работ, услуг для обеспечения государственных и муниципальных нужд, а также по согласованию применения закрытых способов определения поставщиков (подрядчиков, исполнителей) [6].

Таким образом, без чёткого разграничения, но в строгом соответствии с Указом Президента № 314 от 9 марта 2004 г. обозначены родовые и ве- 
домственные функции ФАС России. Как и в нормативных актах, определяющих статус федеральных министерств, в Положении указаны полномочия ФАС России, изложенные в пункте 5 (излагаются в сокращенном виде):

«5. Федеральная антимонопольная служба осуществляет следующие полномочия в установленной сфере деятельности:

5.1. вносит в Правительство Российской Федерации проекты федеральных законов...

5.2. принимает следующие нормативные правовые акты в установленной сфере деятельности...

5.2.9(22).методические указания (методики)...

5.3. осуществляет следующие полномочия по контролю в установленной сфере деятельности...

5.3.2. выдает (направляет):

Заключения...

Предписания....

Предложения...

5.3.3. осуществляет согласование...

5.3.5. устанавливает доминирующее положение хозяйствующего субъекта...

5.3.6. проводит проверку соблюдения антимонопольного законодательства...

5.3.10. возбуждает и рассматривает дела о нарушениях антимонопольного законодательства и законодательства о рекламе...

5.3.15. вносит предложения...

5.3.21. устанавливает (утверждает, регистрирует):

цены (тарифы)...

плату...

предельные (минимальный и (или) максимальный) уровни цен (тарифов)...

5.6. организует прием граждан...

5.12. осуществляет иные полномочия...

5.13. осуществляет в пределах своих полномочий производство по делам об административных правонарушениях».

Таким образом, полномочия рассматриваются как форма реализации функций федеральной службы. Кроме того, как и в случае с министерствами, значительный массив обозначенных полномочий представляет собой функциональные операции, вытекающих из характера организационно-правовых средств (полномочий), посредством которых реализуется родовые и ведомственные функции.

Следует отметить, что вопрос об универсальности функций государственного управления достаточно глубоко разработан как в теории государственного управления, так и в науке административного права. Так, Г.В. Атаманчук отмечает, что функция управления - это «реальное, силовое, целенаправленное, организующее и регулирующее влияние на управляемое явление, отношение, состояние, которое они воспринимают и на которое реагируют». К функциям управления он относит следующие: организация, планирование, регулирование, кадровое обеспечение, контроль [10, С. $124 ; 11$, С. 56$]$.

В монографии «Реализация исполнительной власти в Российской Федерации: Научно-практическое пособие» нами отмечено, что перечисленные функции в научной литературе, как правило, называют общими функциями управления, и солидаризируясь при этом с позицией профессора Д.Н. Бахраха, можно утверждать, что это «всеобщие, типичные способы информационного взаимодействия между субъектами и объектами социального управления. Это устойчивые, относительно специализированные виды административной деятельности вообще»[22].

Д.Н. Бахрах предлагает различать три группы общих функций:

«1. Ориентирования системы: прогнозирования, планирования, нормативного регулирования, методического руководства.

2. Обеспечения системы: кадрового, материально-технического, финансового, организационно-структурного, информационного, правоприменительного.

3. Оперативного руководства системой: непосредственного регулирования деятельности, учета, контроля, оценки (всей работы, отдельных работников, выполнения конкретных заданий и т.д.) и применения мер воздействия (поощрения, наказания и др.)»[13, С. 167-168].

Следует также отметить, что к общим функциям управления, как правило, относят:

1) сбор и обработка (анализ) социальной информации;

2) прогнозирование, т.е. научное предвидение изменений в развитии каких-либо явлений или процессов на основе объективных данных и достижений науки;

3) планирование, т.е. определение направлений, целей управленческой деятельности и способов, средств достижения этих целей;

4) организация, т.е. формирование системы управления, упорядочение управленческих отношений между субъектом и объектом управления, определение прав и обязанностей, структуры органов, организаций, подбор и расстановка кадров и т.д.;

5) регулирование или распорядительство, т.е. установление режима деятельности по достижению целей и задач управления, регулирование поведения управляемых объектов, дача директив, указаний, предписаний и др.;

6) координация и взаимодействие, осуществляемые для достижения общих целей управления; 


\section{Административное и муниципальное право 4 (100) • 2016}

7) контроль и учет, состоящие в том, чтобы установить, соответствует или не соответствует фактическое состояние объекта управления заданному состоянию.

Данный перечень общих функций управления корреспондируется с вышеприведённой таблицей 4 в которой указаны показатели частоты использования терминов, обозначающих основные полномочия органов исполнительной власти.

Необходимо также учитывать, что процесс управления осуществляется в определенной последовательности. Он носит циклический характер и состоит из ряда стадий. Основными стадиями управленческого цикла являются: выработка и принятие решения, организация исполнения решения, контроль за исполнением и подведение итогов.

Таким образом, стадийность управленческого процесса, в которой воплощается реализация функций государственного управления на каждом из этапов, подчёркивает универсализм управленческого процесса, в каждом государственно-властном сегменте общественных отношений - экономическом, социально-культурном, административно-политическом.

В чем заключается позитивное значение указанных методологических подходов?

На наш взгляд, указанные подходы станут методологической основой для подготовки и заполнения классификатора функций и полномочий органа исполнительной власти.

В контексте изложенного следует обратить внимание на зарубежный опыт классификаций функций и полномочий государственного управления, в частности, на КФОГУ (универсальный классификатор функций органов государственного управления).

\section{Выводы:}

Разнообразие подходов к перечню функций и полномочий говорит о необходимости установления более строгого порядка разграничения этих базовых инструментов в области упорядочения деятельности ОИВ в целом.

Организация ведения реестров и классификаторов в условиях государственного управления на основе использования информационных и телекоммуникационных технологий нуждается в обоснованной методологии их выбора и ведения применительно таким объектам как система ОГВ, система ОИВ и в первую очередь ФОИВ, их внутренней инфраструктуры, таких базовых системообразующих параметров деятельности органов исполнительной власти как функции и полномочия. В настоящее время руководством в этой работе является Концепция методологии систематизации и кодирования информации, а также совершенствования и актуализации общероссийских классификаторов, реестров и информационных ресурсов», которая утверждена Распоряжением Правительства РФ в мае 2014 г.

В Распоряжении Правительства РФ от 10 мая 2014 г. № 793-р в разделе «Общероссийские классификаторы» (ОК) предусмотрено, что ОК должны формироваться - в соответствии с Федеральным законом «О техническом регулировании» с учетом Постановления Правительства РФ от 10 ноября 2013 г. № 677 «Об общероссийских классификаторах технико-экономической и социальной информации в социально-экономической области»(далее - ОК), в котором был утвержден перечень из 34 ОК и ответственные за их исполнение ФОИВ [9].

Отмечено, что в настоящее время отсутствуют процедуры работы с ОК и реализуется практика работы по «своим» функциям и разным версиям одних и тех же ОК. Отсутствие необходимых нормативных правовых актов, что ведет к задержкам, а то и отказу от работы с ОК.

Следует отметить и положительные тенденции правового регулирования, направленного на упорядочивание функций и полномочий органов исполнительной власти. Так, Распоряжением Правительства РФ от 20 августа 2015 г. N 1616-р утверждена Концепция оптимизации механизмов проектирования и реализации межведомственного информационного взаимодействия, оптимизации порядка разработки и утверждения административных регламентов в целях создания системы управления изменениями[8]. Данная концепция предусматривает возможности оптимизации отношений, возникающих в связи с предоставлением государственных (муниципальных) услуг соответственно федеральными органами исполнительной власти, органами государственных внебюджетных фондов, органами исполнительной власти субъектов Российской Федерации, а также органами местного самоуправления и иными организациями, участвующими в предоставлении государственных (муниципальных) услуг (далее органы (организации) - исполнители услуг) в соответствии с Федеральным законом «Об организации предоставления государственных и муниципальных услуг» (далее - Федеральный закон).

И хотя Концепция нацелена на синхронизацию информационных систем различных ведомств, при оказании государственных (муниципальных) услуг, она способствует систематизации и оптимизации в целом государственного (муниципального) управления и качественному улучшению процедур взаимодействия государства, физических и юридических лиц. 
При разработке методологии совершенствования систем государственного управления с применением потенциала ИКТ следует проектировать следующее:

1. Разработку общегосударственного реестра функций органов ОГВ, а главное функций ФОИВ Российской Федерации;

2. Общегосударственный реестр полномочий ФОИВ;

3. С учетом названных реестров вырабатывать модели Общеотраслевых классификаторов функций для ФОИВ при ориентации на уровни и виды ФОИВ в системе исполнительной власти РФ.

4. Планировать разработки Общеотраслевых классификаторов функций и полномочий по вертикали ИВ - для уровней: федеральный, субъектов РФ, ОМСУ.

Таким образом, на основании проанализированного материала о состоянии методологии классификации функций и полномочий государственного управления, можно сделать следующие выводы:

1. В теории управления сущность «функция» - это указание на то, в какой области и что делает субъект управления - орган, его подразделения, служащие системы государственной службы. Вторым главным параметром управления является категория «полномочия субъекта управления» - указатель того, каким образом и средствами, закрепленными законодательно, достигает субъект управления реализации своих функций.

2. В законодательной практике до настоящего времени отсутствует чётко сформировавшиеся категории «функция управления» и «полномочие управления».

3. Следствием обозначенной методологической проблемы является подмена понятия функция понятием полномочие в действующих нормативных правовых актах, определяющих правовой статус федеральных органов исполнительной власти; идентичная буквальная трактовка содержания понятий «функция» и «полномочие» в нормативно-правовых актах.

4. Ключ к решению указанных проблем лежит в совершенствовании методологии классифи- каций функций и полномочий государственного управления органов государственной исполнительной власти. Наиболее оптимальной представляется методология, которая рассматривает главные функции управленческих органов как виды воздействий на объекты управления. Они расчленяются на подфункции, действия и операции с разной степенью властности.

5. Данный подход был использован при разработке классификаций функций и полномочий органов государственной исполнительной власти на основе методов сегментации и типологизации.

Сущность метода сегментации функций органов государственной исполнительной власти заключается в выделении общих (родовых) функций федеральных органов исполнительной власти и ведомственных функций федеральных органов исполнительной власти.

Сущность метода типологизации полномочий органов государственной исполнительной власти заключается в выявлении общих или сходных черт используемых в нормативно-правовых актах терминов, отражающих характер полномочия. На основе метода типологизации выделены базовые и частные (отдельные) полномочия федеральных органов исполнительной власти.

6. Соотнесение ведомственных функций и частных (отдельных) полномочий осуществляется посредством метода корреляции, в основе которой лежит парадигма о признании универсализма частных (отдельных) функций для отраслевых (ведомственных) функций органов государственной исполнительной власти.

7. Практическое значение предлагаемой авторами методологии заключается в разработке моделей классификаторов функций и полномочий органов исполнительной власти и методики подготовки и заполнения классификатора функций и полномочий органа исполнительной власти в целях оптимизации государственного (муниципального) управления в соответствующих сферах и качественного улучшения процедур взаимодействия государства, физических и юридических лиц.

\section{Библиография:}

1. Федеральный закон от 27.07.2010 № 210-Ф3 «Об организации предоставления государственных и муниципальных услуг» // "Российская газета", N 168, 30.07.2010.

2. Указ Президента РФ от 01.03.2011 N 248 "Вопросы Министерства внутренних дел Российской Федерации" (вместе с "Положением о Министерстве внутренних дел Российской Федерации") // "Собрание законодательства РФ", 07.03.2011, N 10, ст. 1334.

3. Указ Президента РФ от 12.03.2015 N 129 "Вопросы Министерства иностранных дел Российской Федерации" // "Собрание законодательства РФ", 16.03.2015, N 11, ст. 1587. 


\section{Административное и муниципальное право 4 (100) • 2016}

4. Указ Президента РФ от 09.03.2004 N 314 "О системе и структуре федеральных органов исполнительной власти" (ред. от 22.06.2010) // «Российская газета». № 50, 12.03.2004.

5. Постановление Правительства РФ от 19.06.2012 N 608 (ред. от 03.06.2015) "Об утверждении Положения о Министерстве здравоохранения Российской Федерации" (с изм. и доп., вступ. в силу с 01.07.2015) // "Собрание законодательства РФ", 25.06.2012, N 26, ст. 3526.

6. Постановление Правительства РФ от 30.06 .2004 N 331 (ред. от 04.09.2015) "Об утверждении Положения о Федеральной антимонопольной службе // "Российская газета", N 162, 31.07.2004. (44)

7. Постановление Правительства РФ от 30.06 .2004 N 329 (ред. от 25.07.2015) "О Министерстве финансов Российской Федерации" // "Собрание законодательства РФ", 02.08.2004, N 31, ст. 3258.

8. Распоряжение Правительства РФ от 20.08.2015 N 1616-р «Об утверждении Концепции оптимизации механизмов проектирования и реализации межведомственного информационного взаимодействия, оптимизации порядка разработки и утверждения административных регламентов в целях создания системы управления изменениями» // "Собрание законодательства РФ", 31.08.2015, N 35, ст. 5012.

9. Распоряжение Правительства РФ от 10 мая 2014 г. № 793-р «Концепция систематизации и кодирования информации, а также совершенствования и актуализации общероссийских классификаторов, реестров и информационных ресурсов» // «Собрание законодательства РФ», 19.05.2014, N 20, ст. 2594.

10. Атаманчук Г.В. Теория государственного управления. М.: Юридическая литература, 1997. С. 124.

11. Атаманчук Г.В. Государственное управление (организационно-функциональные вопросы): Учебное пособие. М.: Экономика, 2000. С. 56.

12. Афанасьев М.П., Шаш Н.Н. Российские бюджетные реформы: от программ социально-экономического развития до государственных программ Российской Федерации // Вопросы государственного и муниципального управления. 2014. № 2. С.48-64.

13. Бахрах Д.Н. Административное право России: Учебник для вузов. М.: Норма, 2002. С. 167 - 168.

14. Бачило И.Л. Правовые проблемы организации структур и их функций в системе советского государственного управления: Автореф. дисс. ... на соиск. докт. М., 1979.

15. Бачило И.Л. Методология анализа оценки состояния и совершенствования государственного управления в условиях информатизации / Право и государство: теория и практика. 2015. № 5 (125). С. 135-145.

16. Бачило И.Л. Информационное право: основы практической информатики. Учебное пособие. - М.: Издание Тихомирова М.Ю., 2003.-252 с.

17. Дмитриева Н.Е., Стырин Е.М. Открытое государственное управление: задачи и перспективы в России // Вопросы государственного и муниципального управления. 2014. № 1. С. 127-148.

18. Добролюбова Е.И., Южаков В.Н., Александров О.В. Внедрение управления по результатам в рамках реализации административной реформы в Российской Федерации: на пути к созданию новой модели государственного управления //Вопросы государственного и муниципального управления. 2014. № 2. С. 28-47.

19. Исполнительная власть в Российской Федерации. Проблемы развития. ИГП РАН / Отв. ред. И.Л. Бачило. М.: Юрист, 1998. С. 221-222.

20. Калинин А.М., Кудеркин Д.А., Харитонов М.М. Ведомственные перечни государственных услуг (работ): проблемы формирования и использования // Вопросы государственного и муниципального управления. 2012. № 4. C.84-97.

21. Кирин А.В., Побежимова Н.И. Актуальные проблемы административной реформы // Административное право и процесс. 2014. N 3. С. 67-71.

22. Лапина М.А. Реализация исполнительной власти в Российской Федерации: Научно-практическое пособие. М.: Издательство Института проблем риска, 2006. 238 с. // База «Комментарии к законодательству» СПС КонсультантПлюс.

23. Проект Федерального закона "Об основах государственного и муниципального контроля (надзора) в Российской Федерации" (подготовлен Минэкономразвития России) (не внесен в ГД ФС РФ, текст по состоянию на 25.08.2015 // СПС КонсультантПлюс.

24. Старилов Ю.Н. Административная реформа: способствует ли она совершенствованию административно-правового регулирования? // Актуальные проблемы административного и административно-процессуального права: Материалы научно-практической конференции. М.: Юнити-Дана, 2004.

25. Тихомиров Ю.А. Управление на основе права. М.: Формула права, 2008.

26. Тихомиров Ю.А. Теория компетенции // Журнал российского права, N 10, 2000.

27. Уваров А. Проблемы правового регулирования организации предоставления государственных и муниципальных услуг // Государство и право. 2012. № 2. С. 115-117.

28. Южаков В.Н. Качество государственных и муниципальных услуг: усилия и результаты административной реформы // Вопросы государственного и муниципального управления. 2014. № 1. С. 52-72.

29. Южаков В.Н. Эволюция смыслов и правового регулирования государственных услуг в России в 2004-2012 гг. // Вопросы государственного и муниципального управления. - 2012. - № 2.

\section{References (transliterated):}

1. Federal'nyi zakon ot 27.07.2010 № 210-FZ «Ob organizatsii predostavleniya gosudarstvennykh i munitsipal'nykh uslug» // "Rossiiskaya gazeta", N 168, 30.07.2010.

2. Ukaz Prezidenta RF ot 01.03.2011 N 248 "Voprosy Ministerstva vnutrennikh del Rossiiskoi Federatsii" (vmeste S "Polozheniem o Ministerstve vnutrennikh del Rossiiskoi Federatsii") // "Sobranie zakonodatel'stva RF", 07.03.2011, N 10, st. 1334. 
3. Ukaz Prezidenta RF ot 12.03.2015 N 129 "Voprosy Ministerstva inostrannykh del Rossiiskoi Federatsii" // "Sobranie zakonodatel'stva RF", 16.03.2015, N 11, st. 1587.

4. Ukaz Prezidenta RF ot 09.03.2004 N 314 "O sisteme i strukture federal'nykh organov ispolnitel'noi vlasti" (red. ot 22.06.2010) // «Rossiiskaya gazeta». № 50, 12.03.2004.

5. Postanovlenie Pravitel'stva RF ot 19.06.2012 N 608 (red. ot 03.06.2015) "Ob utverzhdenii Polozheniya o Ministerstve zdravookhraneniya Rossiiskoi Federatsii" (s izm. i dop., vstup. v silu s 01.07.2015) // "Sobranie zakonodatel'stva RF", 25.06.2012, N 26, st. 3526.

6. Postanovlenie Pravitel'stva RF ot 30.06.2004 N 331 (red. ot 04.09.2015) "Ob utverzhdenii Polozheniya o Federal'noi antimonopol'noi sluzhbe // "Rossiiskaya gazeta", N 162, 31.07.2004. (44)

7. Postanovlenie Pravitel'stva RF ot 30.06.2004 N 329 (red. ot 25.07.2015) "O Ministerstve finansov Rossiiskoi Federatsii" // "Sobranie zakonodatel'stva RF", 02.08.2004, N 31, st. 3258.

8. Rasporyazhenie Pravitel'stva RF ot 20.08.2015 N 1616-r «Ob utverzhdenii Kontseptsii optimizatsii mekhanizmov proektirovaniya i realizatsii mezhvedomstvennogo informatsionnogo vzaimodeistviya, optimizatsii poryadka razrabotki i utverzhdeniya administrativnykh reglamentov v tselyakh sozdaniya sistemy upravleniya izmeneniyami» // "Sobranie zakonodatel'stva RF", 31.08.2015, N 35, st. 5012.

9. Rasporyazhenie Pravitel'stva RF ot 10 maya 2014 g. № 793-r «Kontseptsiya sistematizatsii i kodirovaniya informatsii, a takzhe sovershenstvovaniya i aktualizatsii obshcherossiiskikh klassifikatorov, reestrov i informatsionnykh resursov» // «Sobranie zakonodatel'stva RF», 19.05.2014, N 20, st. 2594.

10. Atamanchuk G.V. Teoriya gosudarstvennogo upravleniya. M.: Yuridicheskaya literatura, 1997. S. 124.

11. Atamanchuk G.V. Gosudarstvennoe upravlenie (organizatsionno-funktsional'nye voprosy): Uchebnoe posobie. M.: Ekonomika, 2000. S. 56.

12. Afanas'ev M.P., Shash N.N. Rossiiskie byudzhetnye reformy: ot programm sotsial'no-ekonomicheskogo razvitiya do gosudarstvennykh programm Rossiiskoi Federatsii // Voprosy gosudarstvennogo i munitsipal'nogo upravleniya. 2014. № 2. S.48-64.

13. Bakhrakh D.N. Administrativnoe pravo Rossii: Uchebnik dlya vuzov. M.: Norma, 2002. S. 167 - 168.

14. Bachilo I.L. Pravovye problemy organizatsii struktur i ikh funktsii v sisteme sovetskogo gosudarstvennogo upravleniya: Avtoref. diss. ... na soisk. dokt. M., 1979.

15. Bachilo I.L. Metodologiya analiza otsenki sostoyaniya i sovershenstvovaniya gosudarstvennogo upravleniya v usloviyakh informatizatsii / Pravo i gosudarstvo: teoriya i praktika. 2015. № 5 (125). S. 135-145.

16. Bachilo I.L. Informatsionnoe pravo: osnovy prakticheskoi informatiki. Uchebnoe posobie. - M.: Izdanie Tikhomirova M.Yu., 2003.-252 s.

17. Dmitrieva N.E., Styrin E.M. Otkrytoe gosudarstvennoe upravlenie: zadachi i perspektivy v Rossii // Voprosy gosudarstvennogo i munitsipal'nogo upravleniya. 2014. № 1. S. 127-148.

18. Dobrolyubova E.I., Yuzhakov V.N., Aleksandrov O.V. Vnedrenie upravleniya po rezul'tatam v ramkakh realizatsii administrativnoi reformy v Rossiiskoi Federatsii: na puti k sozdaniyu novoi modeli gosudarstvennogo upravleniya // Voprosy gosudarstvennogo i munitsipal'nogo upravleniya. 2014. № 2. S. 28-47.

19. Ispolnitel'naya vlast' v Rossiiskoi Federatsii. Problemy razvitiya. IGP RAN / Otv. red. I.L. Bachilo. M.: Yurist, 1998. S. $221-222$.

20. Kalinin A.M., Kuderkin D.A., Kharitonov M.M. Vedomstvennye perechni gosudarstvennykh uslug (rabot): problemy formirovaniya i ispol'zovaniya // Voprosy gosudarstvennogo i munitsipal'nogo upravleniya. 2012. № 4. S.84-97.

21. Kirin A.V., Pobezhimova N.I. Aktual'nye problemy administrativnoi reformy // Administrativnoe pravo i protsess. 2014. N 3. S. 67-71.

22. Lapina M.A. Realizatsiya ispolnitel'noi vlasti v Rossiiskoi Federatsii: Nauchno-prakticheskoe posobie. M.: Izdatel'stvo Instituta problem riska, 2006. 238 s. // Baza «Kommentarii k zakonodatel'stvu» SPS Konsul'tantPlyus.

23. Proekt Federal'nogo zakona "Ob osnovakh gosudarstvennogo i munitsipal'nogo kontrolya (nadzora) v Rossiiskoi Federatsii" (podgotovlen Minekonomrazvitiya Rossii) (ne vnesen v GD FS RF, tekst po sostoyaniyu na 25.08.2015 // SPS Konsul'tantPlyus.

24. Starilov Yu.N. Administrativnaya reforma: sposobstvuet li ona sovershenstvovaniyu administrativno-pravovogo regulirovaniya? // Aktual'nye problemy administrativnogo i administrativno-protsessual'nogo prava: Materialy nauchnoprakticheskoi konferentsii. M.: Yuniti-Dana, 2004.

25. Tikhomirov Yu.A. Upravlenie na osnove prava. M.: Formula prava, 2008.

26. Tikhomirov Yu.A. Teoriya kompetentsii // Zhurnal rossiiskogo prava, N 10, 2000.

27. Uvarov A. Problemy pravovogo regulirovaniya organizatsii predostavleniya gosudarstvennykh i munitsipal'nykh uslug // Gosudarstvo i pravo. 2012. № 2. C. 115-117.

28. Yuzhakov V.N. Kachestvo gosudarstvennykh i munitsipal'nykh uslug: usiliya i rezul'taty administrativnoi reformy // Voprosy gosudarstvennogo i munitsipal'nogo upravleniya. 2014. № 1. S. 52-72.

29. Yuzhakov V.N. Evolyutsiya smyslov i pravovogo regulirovaniya gosudarstvennykh uslug v Rossii v 2004-2012 gg. // Voprosy gosudarstvennogo i munitsipal'nogo upravleniya. - 2012. - № 2. 